\title{
高濃度塩化物溶液中における二相ステンレス鋼と その溶接継手部の応力腐食割れ特性
}

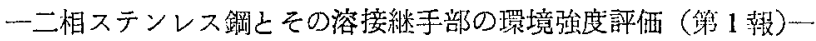

问井 急彦**，村田 雅人**

Characteristics of Stress Corrosion Cracking of Duplex Phase Stainless Steel and Welded Joints in High Concentration Chloride Solution*

-Estimation of Strength of Duplex Stainless Steel in Corrosive Environments (Report I)-

by Yoshihiko Mukai** and Masato Murata**

Susceptibility of stress corrosion cracking (SCC) of duplex stainless steel, SUS329 $9_{\mathrm{J}} 1$ was investigated in $42 \% \mathrm{MgCl}_{2}$. aq. sol. ( $416 \mathrm{~K}$ ). Results were as follows:

Effect of structural anisotropy for SCC were studied. It was made clear that SCC was more susceptible in the case of crack growth being parallel to main rolling direction than in other cases and crack tend to propagate along $\alpha$ phase other than $\gamma$ phase. In addition, SCC susceptibility was remarkably high in welded plates, although $329_{\mathrm{J}} 1$ base metal had high resistance to SCC. This would be caused that the residual stress were higher for its high yielding strength of base metal.

Key Words: Duplex stainless steel, Crack growth rate, Stress intensity factor, anisotropy, rolling direction, Keying effect

\section{1. 緒}

\section{言}

二相ステンレス鋼は，特に耐孔食性に優れ高溓度塩化 物溶液中で屯高い酎食性を示すう。まな，他のオーステ ナイト系ステンレス鋼と比較すると高い強度を有する が，組織としては $\gamma$ 相が圧延方向に伸長し，顕著な組織 的異方性が存在する。二相ステンレス鎆ならびにその浴 接継手の酎食性と環境強度を有效に利用するためには， その組織的異方性の影響について知る必要がある。

そこで，本研究では䯩濃度塩化物溶液中における活性 経路腐食（APC SCC）感受性におよほす異方性の効果 について検討を行い，あわ甘て溶接継手部におりる環境 強度評価む行った。

\section{2. 供試材料ならびに実験方法}

供試材料は市販の SUS329J1 で受入れの状態で使用 した. Table 1 に化学組成を示す．また，溶接としては TIG（入熱約 $20000 \mathrm{~J} / \mathrm{cm} ， 1$ 圈，メルトラン）を行っ te.

Table 1 Chemical composition of material used

\begin{tabular}{|c|c|c|c|c|c|c|c|c|}
\hline & $\mathrm{C}$ & $\mathrm{Si}$ & $\mathrm{Mn}$ & $\mathrm{P}$ & $\mathrm{S}$ & $\mathrm{Ni}$ & $\mathrm{Cr}$ & $\mathrm{Mo}$ \\
\hline $329 \mathrm{~J}$ & 0.076 & 0.51 & 0.32 & 0.032 & 0.007 & 4.25 & 24.72 & 1.83 \\
\hline
\end{tabular}

試験としては，SCC 破断契命試験，き裂伝播試験，溶 接残留応力下での SCC 試験を行った。それれぞれに使用 した試験片形状を Fig. 1 (a)，(b)，(c) 亿示す。 また，図中 には試験片採取方向ああわせて示す（板厚方向の試験片 はつかみ部を電子ビーム溶接して試験に供した). SCC 破断寿命試験は試験環境中で試料を定荷重破断しその破 断寿命を測定した．SCC 伝播試験は片側切久付曲げ武 験片を試験環境中に部分浸演し，定荷重曲げにより先端 半径約 $0.05 \mathrm{~mm}$ のスリットより $\mathrm{SCC}$ を発生伝播させ た. SCC 長さは試験槽外部に設置した約22倍の光学顕

* 原稿受付 昭和60年 5 月 7 日 昭和60年度春季全国大会で発㠇

** 正 貝 大阪大学工学部 Member, Osaka University

a) Smooth tensile specimen
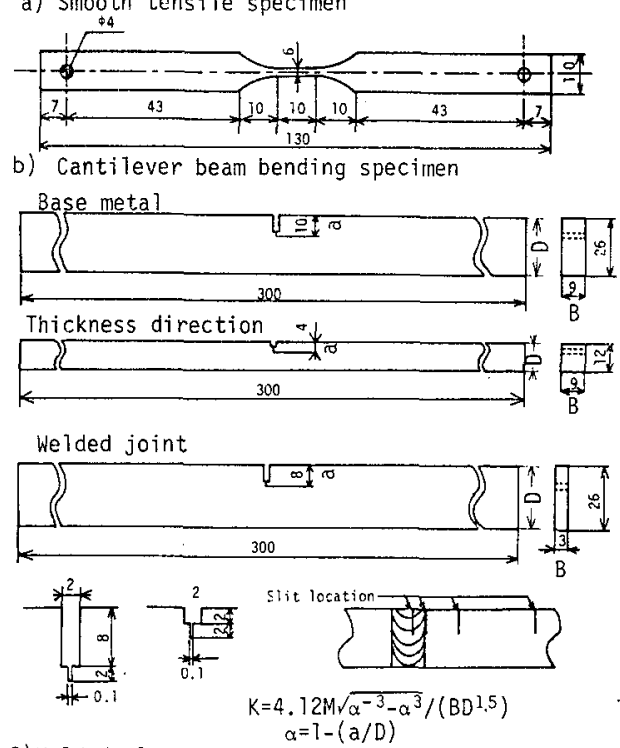

C) Welded plate

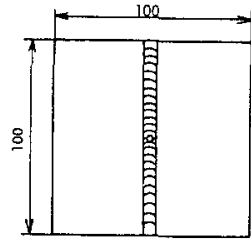

$t=5$

Cutting plan
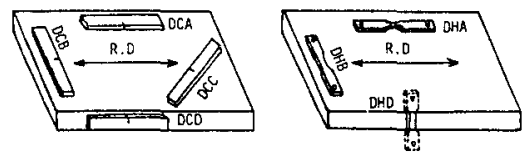

unit:m

Fig. 1 Dimensions of test specimens 

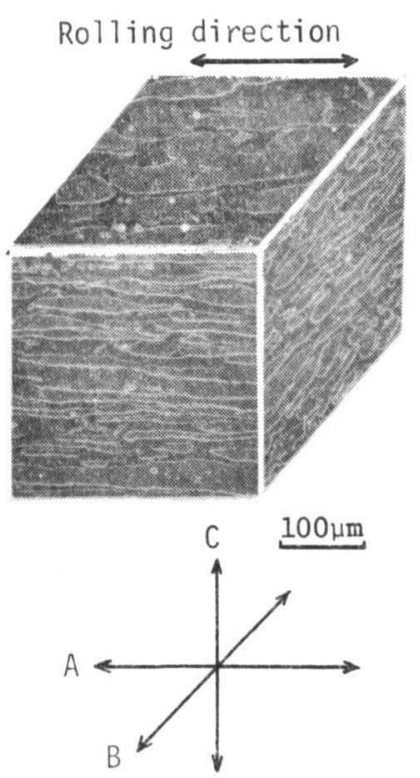

loading direction

Fig. 2 Structure and loading direction

Table 2 Mechanical properties of materials

\begin{tabular}{|c|c|c|c|c|}
\hline L.D. & A & B & C & W.M \\
\hline$\sigma_{02} / \mathrm{MPa}$ & 461 & 490 & 421 & 559 \\
\hline U.T.S/MPa & 772 & 752 & - & - \\
\hline
\end{tabular}

L.D. : Loading direction

微鏡を用いて直読し, 図中に示す式により $K$ を算定し, き裂层播速度 $d a / d t$ と $K$ の関係を求めた. ここで, 試 験環境は $42 \%$ 沸滕 $\mathrm{MgCl}_{2}$ 水溶液 $(416 \mathrm{~K})$ とした。

Fig. 2 は用いた SUS329J1 の金属組織であるが， $r$ 相 と $\alpha$ 相が層状にならび主圧延方向に伸長した組織形態を 示し, 顕著な組織異方性が認められる。以下, 荷重軸と 圧延方向の相関関係によって異方性の影響を論じるが, 荷重軸の方向は図中 A, B , C とする.

Table 2 は, 各荷重軸方向に対する機械的性質であ る. 荷重方向が圧延方向に平行 (A), 直角 (B) の場合, 比較的高い耐力を有するが板厚に刘して垂直方向の引張 （C）に対しては若干の強度低下が認められる。

\section{3. 実験結果亡考察}

\section{1 母材部における SGG 特性}

SUS329J1 母材の SCC 感受性におよぽす組織異方性 の影響について検討した. Fig. 3 に圧延方向に平行 (A), 直角 (B), 板厚に直角方向 (C) に荷重を付加した場合 の SCC 破断寿命特性を示す. 図中には参考のためSUS 304 鋼のデータ2) ああわせて示す。二相ステンレス鋼は オーステナイト系ステンレス錆よりあ高い SCC 抵抗性 を示し, 耐孔食性とあわせて耐環境強度特性屯優れてい る様子がうかがえる。また，二相ステンレス鋼は特に荷 重軸方向と圧延方向が平行な場合（A）に SCC 抵抗性 が高く, 垂直 (B), さらに板厚方向の負荷 (C) と抵抗 性は低下し, SCC に対するかなり顕著な組織異方性の 影響が慧められる。すなわち、二相ステンレス銅を実使

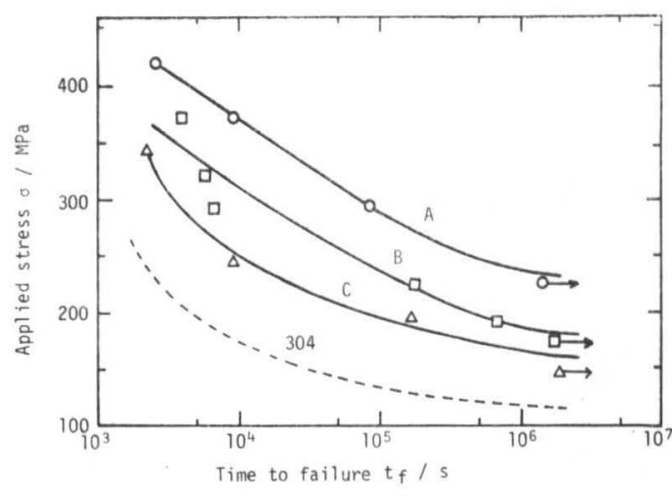

Fig. 3 Relation between applied stress and time to failure

用に供する場合はこのような組織異方性の影響を十分に 考慮する必要があり, 最大主応力の働く方向と圧延方向 を一致させることが最高の環境強度を得るのに必要かと 思われる.

次に, SCC 伝播の様相についてさらに詳しく知るた めに, Fig. 4 に片側切欠付曲げ試験片を用いた場合のス リット先端部からのき裂の進展の様子を示す. SCC は スリットが圧延方向に直角あるいは平行に人っている場 合は単一き裂で進展するが, 圧延方向に $45^{\circ}$ 傾斜するよ うにした試験片ではき裂分岐が生じ, 圧延方向に平行む しくは直角に伝播する. 特に, 分岐き裂中圧延方向に平 行に伝播しているき裂は直角のそれよりあき裂長さは長 く, より伝播し易いことがわかる. さらに, 板厚方向に 伝播する場合は SCC は不規則なき裂分岐を生じる。乙 れは板厚方向に特に密に $\gamma$ 相， $\alpha$ 相が層状にならび組織 的不均一が著しいことあ原因しているかと思われる. Fig. 5 は各 $d a / d t$ と $K$ の関係であるが, SCC 层播速度 は圧延方向に平行にき裂が進展する場合が高く,ついで 垂直, さらに板厚方向に垂直に進むむのが最す低くなる
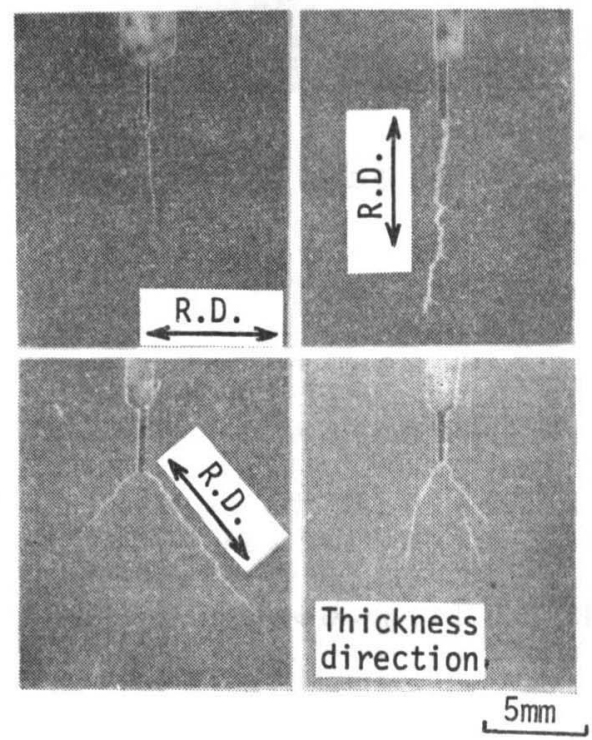

Fig. 4 Relation between rolling direction and crack growth direction 


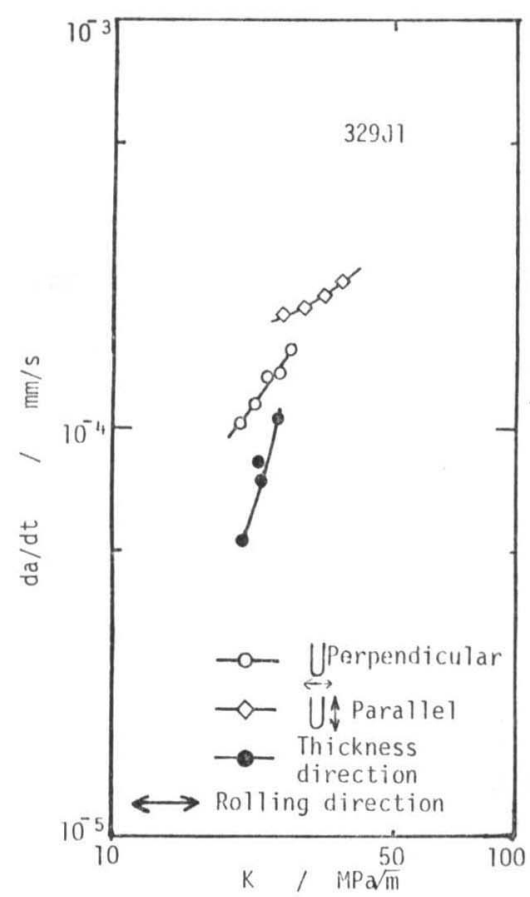

Fig. 5 Relation between $d a / d t$ and $K$ (Base metal)

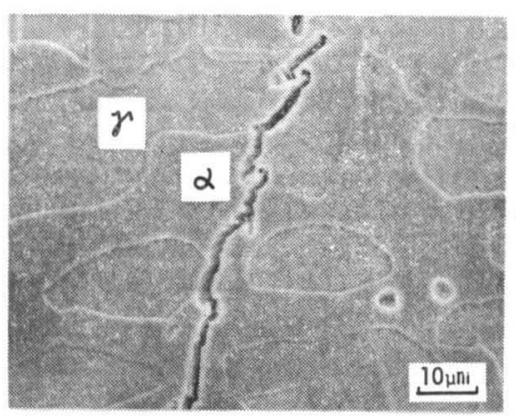

Fig. 6 Appearance of SCC growth (Base metal)

傾向が認められる.そこで, 各試料の金属組織とき裂层 播の様相を観察した 1 例を Fig. 6 に示す.ささらに，き裂 层播方向と $\gamma$ 相の分布状態がき裂伝播速度に対し大きな 影響をむつと考えられるので次に，き裂が $0.5 \mathrm{~mm}$ 進展 する間に $\gamma$ 相と遭遇する頻度を求めた結果を Fig. 7 に示 す.とのように, き裂が圧延方向に平行に進展する場合 はその頻度は低く, 直角, 板厚方向とその頻度は高くな り,き裂が $\gamma$ 相之遭遇する頻度が高い程 SCC 伝播速度 は低下する.すなわち， $\gamma$ 相はき裂の伝播に対する一種 の阻止効果を有すると見なせる. Fig. 6 において見られ たき裂の分岐は $\gamma$ 相が阻止効果を有するため，き裂が $\alpha$ 相の連続的に並ぷ方向あるいは $\gamma$ 相中を伝播する距離を 最小にする方向（ $\gamma$ 相に対して直角方向）に選択的に進 展した結果生じたものと考えられる，また，平滑材の破 断寿命試験において荷重軸が圧延方向と平行 (A) の場 合に最も SCC 抵抗性が高かったが，とれはき裂が $\gamma$ 相 を最む回避して進展しにくく，また $\gamma$ 相との遭遇率も高 い方向であり，本質的には SCC 层播試験結果と同傾向

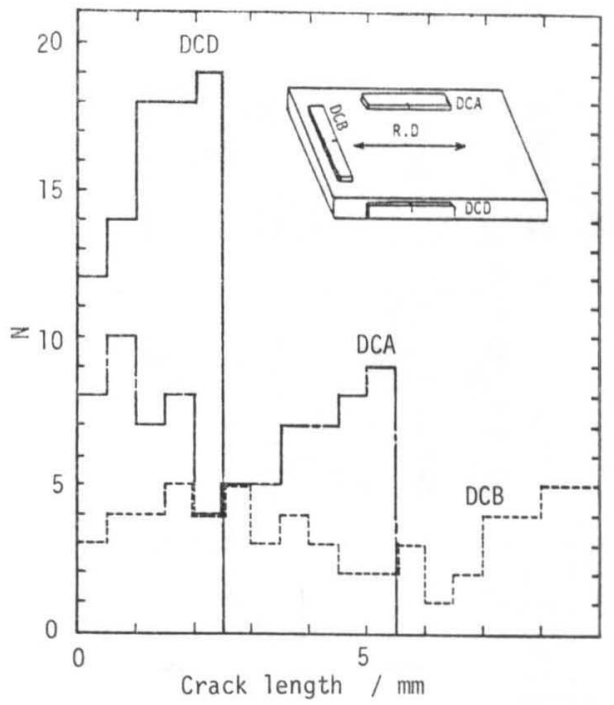

Fig. 7 Frequency of crack passing through $\gamma$ phase

を示し, やはり $\gamma$ 相の阻止効果が主原因と見なすととが できよう.ただし，従来より $\gamma$ 粗地中に $\alpha$ 相粒子が存在 する場合には， $\alpha$ 相が阻止效果を有することがいわれて いる，ここでは， $\gamma$ 粒子が逆に阻止効果を有する実験結 果となっている，てれは，粗地が $\alpha$ 地であり電位的にか なり卑方向にあるために, $\gamma$ 相が $\alpha$ 相によって強く陰極 防食をうけたととが原因と思われるが，その詳細につい てはさらに検討を進める必要がある。

\section{2 溶接継手部における SCC 特性}

溶接継手部におりる SCC 感受性を知るために，平滑 試験片（余盛削除）を用いた場合の SCC 発生位置なら びに破断位置を Fig. 8 に示す.ここで負荷応力はすべて $350 \mathrm{MPa}$ とした. SCC 発生頻度は主に溶接金属部と HAZ 粗粒域で高く，母材域では全く SCC は生じてい ない. Fig. 9 は溶接継手部各位置での組織変化の様相を 示したあのであるが, ボンド部, 溶接金属部では母材に おりる $\alpha$ 相， $\gamma$ 相の層状組織は見られず，大きな $\alpha$ 結晶 粒之粒界に $\gamma$ 相が析出（粒内にも $\gamma$ 相は微細析出）した 組織を呈する. その $\alpha$ 相と $\gamma$ 相の画像処理二值解析法に よる測定值は，母材で $\gamma=50 \% ， \alpha=50 \%$, 溶接金属で は $\gamma=43 \%, \alpha=57 \%$ となり, 溶接金属部で $\gamma$ 量は低下 していた.すなわち, 溶接金属部において SCC感受性が 高いのは $\gamma$ 相の量的低下とその徽細析出のためにき裂に

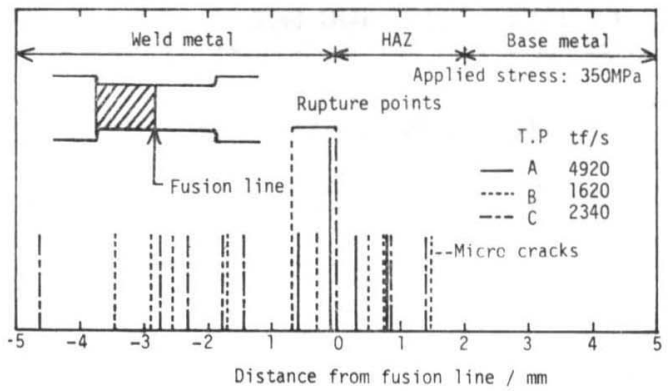

Fig. 8 Distribution of SCC initiation in welded smooth specimens 

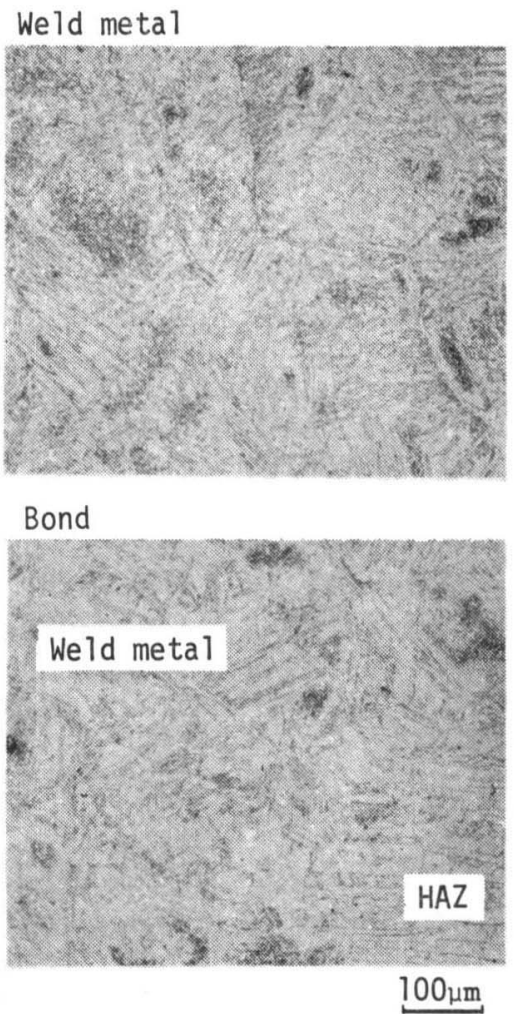

Fig. 9 Structures in welded joint

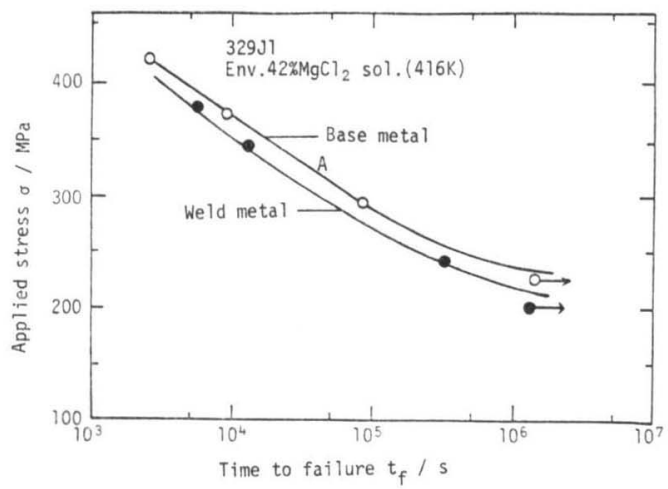

Fig. 10 Relation between applied stress and time to failure

対する阻止効果が母材の場合程, 有効に働かないととが 主原因の 1 つと考えられる。 また, 特に溶接金属部の SCC 発生頻度が高いのは母材部之のマクロセルの形成 の効果ああろうかと思われる.

次に，溶接金属部における SCC 破断寿命を測定した 結果を Fig. 10 亿示す. これは, 溶接金属のみを露出し て他の部分をシリコンゴムでコーティングした平滑試験 片を使用した場合の屯のである. 図中には参考のため に, 引張方向之圧延方向が平行の場合の母材特性ああわ せて示す．とのように，溶接金属部はわずかではあるが SCC 感受性は高くなっている. Fig. 11 は溶接継手各位 置における $d a / d t$ と $K$ の関係であるが，ボンド部，溶

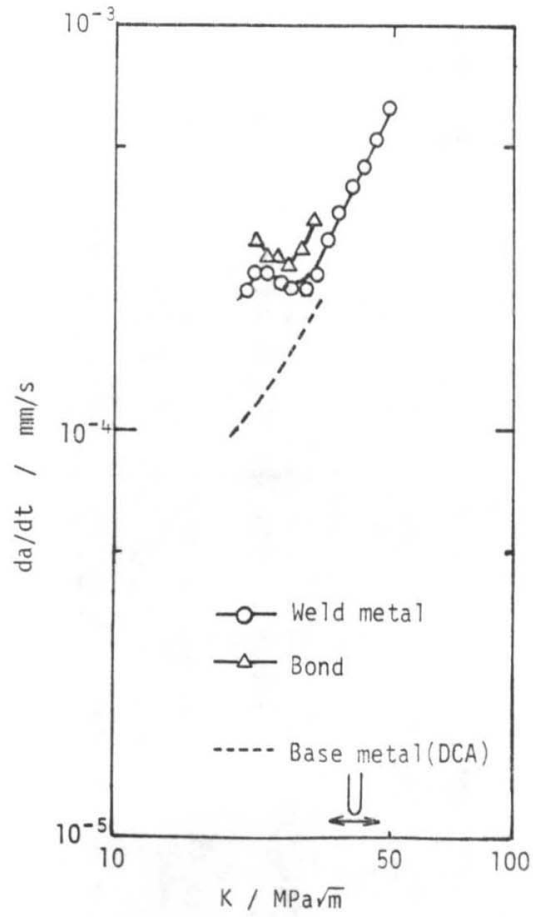

Fig. 11 SCC propagation feature in SUS 329J1 welded joint

接金属，母材部の順にき裂层播速度は低下し SCC の平 滑材における発生頻度と傾向的に対応している. また， ボンド部, 溶接金属部における SCC 伝播速度は種々の 荷重方向に対する母材のそれよりあすべて高く，特に SCC 感受性が高いととがわかる。一方, SCC 破断寿命 試験結果より，溶接金属部の方が荷重軸が圧延方向と直 角のあのよりあ SCC 感受性が低いように見られるが, これは溶接金属の耐力がそれに比べ約1.14倍と高くなり 同荷重におりるすべりステップ3) が母材よりあ小さく, SCC 発生に対する潜伏期が長くなったことが原因と思 われる（溶接金属部に発生したき裂はたとえ耐力が高く き裂先端におけるすべりステップが小さくてあ， $\gamma$ 粒子 による阻止効果が小さいために結果としてき裂伝播速度 が母材よりあ高くなったあのであろう).

\section{3 溶接継手部の環境強度評価}

以上の実験結果より，二相ステンレス鋼母材における 塩化物応力腐食割れ感受性は SUS304 鋼のようなオー ステナイト系ステンレス鋼よりも優れているととが明ら かとなった，そこで，溶接継手部の環境下における強度 を知るために, 溶接残留応力下における SCC の発生に ついて検討を行った. Fig. 1 (c) に示した溶接継手板を42 $\% \mathrm{MgCl}_{2}$ 水溶液 $(416 \mathrm{~K})$ 中に $2.30 \times 10^{5} \mathrm{~s}$ 漫漬した. その結果 Fig. 12 に示すように, やはり SCC を発生し 二相ステンレス鋼といえどあ溶接継手部においては高い SCC 感受性を有しているといえる。同試験片における 溶接残留応力をひずみゲージ法で実測すると4)，相当応 力で最大 $260 \mathrm{MPa}$ の残留応力が生じ，0.29 耐力の約 $1 / 2$ 程度 (ゲージ長 $1 \mathrm{~mm} の 2$ 軸ひずみゲージにより測 定）であった。 そこで，Fig. 3 亿示した破断寿命線図を 耐力 $\left(\sigma_{0.2}\right.$, 室温 $)$ を基準として再整理した図を Fig. 13 

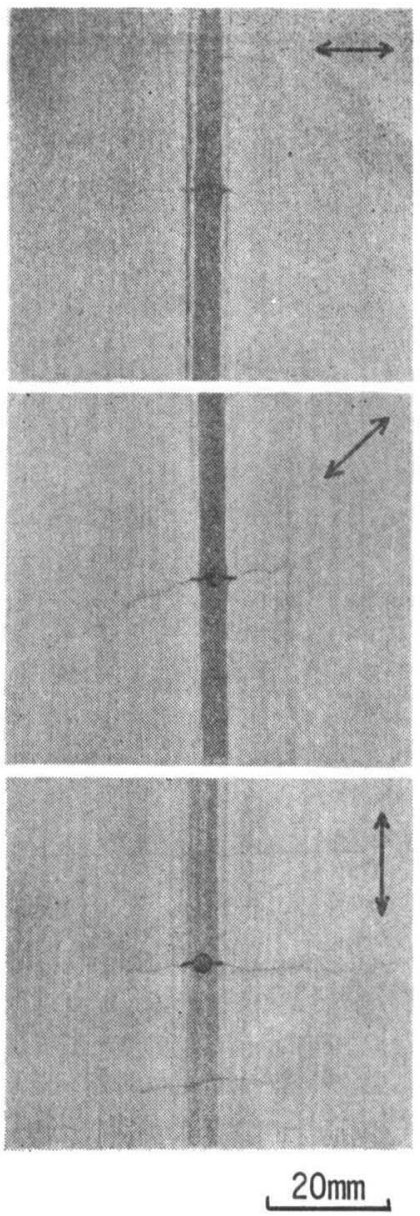

$\longleftrightarrow$ Rolling direction

Fig. 12 Appearance of SCC growth in welded plates

に示す.とのように，二相ステンレス鋼と 304 ステンレ ス鋼の応力腐食割れ感受性は耐力比で整理するとほほ同 程度となる，すなわち，二相ステンレス鋼の耐応力腐食 割れ性能は主に $\gamma$ 相の阻止効果ああるが耐力の上昇によ るところが大きいように考えられ，一方，母材の耐力が 高い程溶接残留応力む上昇することあ考えあわせると，

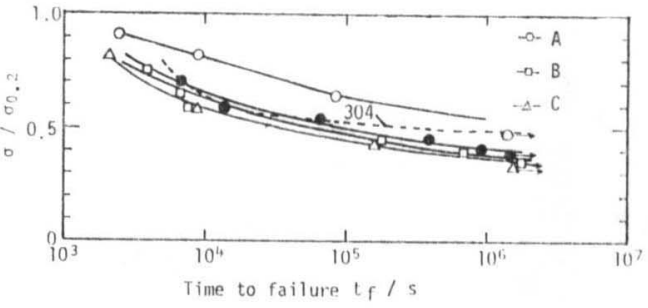

Fig. 13 Relation between normalized stress by $\sigma_{0.2}$ and time to failure

溶接継手部においては二相ステンレス鋼といえども母材 の物性は十分に発揮できず必ずしあ安全でないといえ る. この点は, 実際の構造物の設計に際しては十分に留 意する必要があり, 何らかの残留応力の軽減に関する積 極的方策を講じる必要があると思われる。

\section{4. 結言}

以上, 得られた結論を要約すると次の通りである。

1）二相ステンレス鋼の環境強度は組織的異方性の影 響を強く受け, 特に荷重軸が圧延方向と平行な場合に高 い SCC 抵抗性を示す.

2）き裂と $\gamma$ 相との遭遇頻度が高い程, SCC 层播速 度は低下し $\gamma$ 相はき裂伝播に対する阻止効果を有すると みなせる。

3）二相ステンレス鋼の高濃度塩化物中における高い SCC 抵抗性は, 主にその高い降伏強度と $\gamma$ 相の SCC 伝播に対する阻止効果に起因している.

4）溶接金属部は母材と比較して SCC 伝播の感受性 が高く, $\gamma$ 量の低下とその微細析出による阻止効果の低 下が主原因の 1 つと思われる。

5）溶接継手部の性質としては，母材の降伏点が高い 程残留応力む上昇するので, 二相ステンレス鋼において あ溶接部では母材の優れた性質が生かされず，かなり高 い SCC 感受性を有する.

おわりに, 本研究の遂行に当り試料のご提供をいただ いた日本鋼管侏中央研究所に感謝致します。また，本実 験の実施に多大など協力をいただいた当時, 大阪大学 4 年, 增田勝弘君 (現, ダイハツ工業(棑) に謝意を表しま す.

\section{参考文 献}

1）小若正倫：日本金属学会会報, 17 (1978), 657

2）村田雅人，向井喜売：日本金属学会誌, 44-3 (1980)

3）村田雅人, 向井喜裳：日本金属学会誌, 44-7 (1980)

4) 向井喜彦，村田雅人，溶接学会憙，49-3 (1980)

\section{2 相ステンレス鋼溶接部の耐孔食性に及ぼす B 添加の影響*}

中尾 嘉邦**, 西本 和俊**, 堀井 宏真***

Effect of Boron on the Pitting Corrosion Resistance in HAZ of Duplex Stainless Steels*

by Yoshikuni Nakao**, Kazutoshi Nishimoto** and Hiromasa Horii***

A study has been performed to determine the effect of boron on the pitting corrosion resistance in

\footnotetext{
$*$ 原稿受付 昭和 60 年 6 月 24 日 昭和 58 年度春季全国大会で発表

** 正 員 大阪大学 Member, Osaka University

*** 正 員大阪大学大学院(現, 日本酸素(株)) Member, Graduate

School, Osaka University. (Present Adress,

Japan Oxyger Co., Ltd.)
} 